\title{
Internet Integration in EFL College Instruction: Attitudes and Perspectives
}

\author{
Abdulhafeed Saif Modhish \\ English Department, Taiz University, Yemen \\ abdulhafeed70@gmail.com \\ Abdu M. Talib Al-Kadi \\ Center of Languages \& Translation, Ibb University, Yemen \\ findtalib@gmail.com
}

\begin{abstract}
This paper explored how the Internet is used and manipulated in enhancing the teaching and learning of English as a foreign language at Taiz. University, Yemen. 20 EFL instructors, affiliated to both Arts and Education colleges, participated in the survey. To address the research questions raised in this paper a questionnaire of closed and open questions was used to obtain relevant data that were analyzed both statistically and qualitatively. Findings of the study reveal that there is a high level of agreement among the participants that the Internet plays a significant role in learning and teaching English as a foreign language. Findings also show that the surveyed instructors are quite aware of the importance of the Internet and, as a consequence, they utilize it in various ways to further enhance their classroom teaching. Moreover, analysis of the data showed that there are no statistically significant differences among the respondents regarding Internet applications in TEFL based on gender/college affiliation and age variables. The paper concludes with some recommendations that draw attention to the importance of Internet-Based Language Learning (IBLL) in second/foreign language contexts.
\end{abstract}

Keywords: EFL Instructors, EFL Context, Internet-Based Language Learning (IBLL)

\section{INTRODUCTION}

The emergence of the Internet has, in fact, substantially changed the way ELT is tackled, especially in privileged places where the Internet access is made available. The Internet, in other words, is regarded as an indispensible source of knowledge, ideas, and learning resources, particularly in the field of language learning and teaching. It is considered a vast source of language learning tools and resources. To be more specific, it can be used to retrieve and access not only teaching and learning materials but also more recent classroom techniques that can specifically work in the foreign language context.

Innovative and creative as it is, the Internet has contributed to a shift of focus from the traditional teacher-centered approaches to learner-centered approaches. Simply put, the Internet can play a potentially significant role in enhancing self-directed learning, teaching and learning of critical thinking skills, collaborative learning, learner autonomy, just to mention a few (Al-Mekhlafi, 2004; Crystal, 2006; Wu, Yen \& Marek, 2011). Emphasizing the role of the Internet as a great source of innovative ideas and insights, Sperling (1998) states that "the Internet is like a library which is five minutes old" (p.4). Further, McDougald (2009) argues that the Internet has marvelously turned the world into a convenient place where information can be easily and comfortably retrieved and shared by people across the globe.

Specifically, the advent of the Internet, along with its sophisticated software programs, search engines like Google and Yahoo and social media networks such as Facebook and Twitter has tempted language teachers across the globe to seriously consider integrating it in second/foreign language teaching and learning. To clarify more, researchers concerned with L2 learning and teaching believe that the Internet can be a tremendous source of innovative ideas for teaching and learning languages, providing a variety of language resources that can be used to serve language learning purposes (Moore, 1996; Pennington, 1996; Smith, 1997; Warschauer, 2000). Likewise, Singhal (1997) argues that the Internet provides supplementary language activities, which can provide learners with carefully 
planned practice in certain areas of language learning including reading texts and reading-related exercises that are meant to foster learners' repertoire of tackling familiar and unfamiliar texts. In addition, the Internet, Singhal argues, can provide learners with language exercises that can generally enhance their L2 competence.

Additionally, as L2 learning facilitators, language teachers can recommend certain ESL/EFL sites on the Web that would be useful for teaching and learning purposes. Crystal (2006) points out that "Websites can provide a greater variety of materials, attractively packaged, such as newspaper articles, quizzes, exercises, self-assessment tasks, and other forms. As a publishing medium, moreover, the Web offers unprecedented opportunities to students, for both individual and collaborative work" (p. 269).

Levy (2009) suggested several Internet-based tools and applications to improve the language skills. For instance, he proposed using podcasts to enhance listening and cultural aspects; wikis, blogs, emails and e-dictionaries to enhance reading and writing; Skype, Vibre, WhatsApp to enhance communicational skills. In fact, the roles of these Internet tools/applications are blurred; a single one (e.g. Facebook) might be useful to enhance more than one language skill and thus an integration of the skills can be achieved.

Kitao and Kitao (2001) maintained that teachers should not only teach learners how to find resources on the Internet, but how to filter these resources. The authors elaborated on how to direct the Internet for learning/teaching purposes: finding websites, search engines, links pages, etc. It should not be taken for granted that the language learners are quite familiar with learning form the Internet; it is the teachers' responsibility to guide this utilization.

Hismanoglu (2011) examined the attitudes of language teachers towards Internet-based foreign language teaching at the English preparatory school of the European University of Lefke, Turkey. Employing a questionnaire as a means of data collection, the researcher found that the teachers had positive attitudes towards the integration of the Internet in their teaching. Results also revealed that the teachers in question were aware of the importance of the Internet in providing them with innovative ideas and techniques that they could effectively use in their classrooms. According to Hismanoglu, the surveyed teachers stressed the fact that their Internet-based teaching would make their teaching more interesting and would enable them to rely less on the traditional approaches and methodologies.

In a similar vein of research, Shin and Son (2007) examined Korean secondary school EFL teachers' perceptions and perspectives on the use of the Internet for teaching purposes. Though findings showed positive views regarding the use of the Internet for teaching EFL, teachers had difficulties in finding appropriate teaching materials and in integrating the Internet resources into their teaching. The study documented three factors that had affected the use of the Internet in the classroom. One of these factors is the teachers' personal interest in Internet use, and the second factor is related to the teachers' abilities in integrating Internet resources into classroom activities. The last factor has to do with the Internet infrastructure available in schools. Similarly, Noytim (2006), in a case study that explored the impact of the Internet on English language teaching in Thailand, found that due to difficulty in gaining access to the Internet by students and lack of knowledge as to how to effectively use the Internet, Thai EFL learners used the Internet as an add-on tool rather than as an integral part of their study. Despite all this, it was found that the Net is highly valued as a powerful resource for teaching English as an L2.

To wrap things up, research conducted on the use and manipulation of the Internet in language learning and teaching (e.g. Dudeney \& Hockly, 2012; Crystal, 2006; Gündüz, 2005 ;Singhal, 1997) has clearly demonstrated that the Internet can be used in language education to enable language learners to further improve their language skills by capitalizing on the various language learning resources offered by the Internet.

\section{RESEARCH QUESTIONS}

The present paper aims to explore the extent to which the Internet is used in enhancing the teaching and learning of English as a foreign language in the Yemeni context. It thus seeks to address the following research questions.

1. To what extent do the EFL instructors utilize their Internet-based skills in enhancing EFL classroom instruction? 
2. To what extent is the Internet-related knowledge possessed by EFL instructors capitalized on to provide language learners with adequate language input?

3. What are the Internet-based tools that EFL instructors employ to maximize learners' use of the target language?

4. Are there any statistically significant differences with regards to the Internet applications in TEFL based on age/college/gender variables?

\section{Methodology}

Given the aims and purpose of the current study, the descriptive approach was adopted to analyze and describe the data collected from the 20 EFL instructors who participated in this study. Data obtained was thus analyzed objectively and qualitatively.

\subsection{Instrument}

A 28-item questionnaire, composed of five parts, was designed by the researchers to collect data regarding the use of the Internet by Taiz University (henceforth TU) EFL instructors to further enhance their classroom teaching. Questions concerning the participants' bio-data and college affiliation (gender, college, qualifications, etc.) are incorporated into the first part. The second part includes questions concerning teachers' experience with the Internet. The third part is related to the Internet applications in TEFL. The fourth part is concerned with the impact of the Internet on EFL learners. The last part probes further comments and suggestions put forward by the participants. Three types of questions were used in the questionnaire - closed ended questions with a multiple choice (Q1-10); scalar items (1-19 in part III) based on a five-point scale ranging from strongly disagree, to strongly agree, and items 10-17 (in part IV) are similarly a five-point scale ranging from never to always, and the last part is an open-ended question.

Prior to administrating the questionnaire, its psychometric features (validity and reliability) were checked. Using SPSS, the questionnaire had a Cronbach's Alpha reliability coefficient of 0.87 which shows a good degree of internal consistency among the items of the instrument.

\subsection{Participants}

20 English instructors (males and females) from Arts and Education colleges at Taiz University participated in this study. They hold $\mathrm{PhD}, \mathrm{MA}, \mathrm{BA}$ degrees, and the majority of them are Yemenis, graduated from local and foreign universities. They are aged between 27 and 60, and specialized in ELT, English Literature, and Linguistics. They are all engaged in teaching language, literature and linguistics courses to the undergraduate students enrolled in the four-year EFL program at TU.

\section{Data Analysis}

Given the nature of the current paper, obtained data were analyzed both statistically and qualitatively. All the questionnaires distributed to the participants were received, with a return rate of $100 \%$, and subjected to thorough analysis. Data were thus categorized and analyzed statistically via the Statistical Package for Social Science (SPSS, version 21) which required converting the respondents' answers into numbers and percentages. Descriptive statistics for the totals, frequencies, and percentages were obtained, classified, transformed into numerical values, and arranged in Tables 1, 2, 3. Moreover, data obtained from the open-ended question were analyzed rather qualitatively.

\section{RESUlTS AND DISCUSSION}

This paper is an investigation into the use of the Internet by EFL instructors to enhance English language instruction at Arts and Education colleges at T U. Analysis of the data obtained from the questionnaires yielded the results outlined below, and the section to follow is devoted to answering the questions raised in the paper.

Q (1) To what extent do the EFL instructors utilize their Internet-based skills in enhancing EFL classroom instruction?

EFL instructors' familiarity with the Internet, as reflected in item 7 of the questionnaire, shows that all the 20 surveyed teachers are Internet users. This means that they are quite aware of the importance of the Internet in language teaching and learning. In addition to this, $71 \%$ of the surveyed teachers indicated that they had home-based Internet connection. However, $29 \%$ of the teachers stated that they had no Internet connection in their homes. 
Table1. Teachers' Self-rating of their Computer/Internet Skills

\begin{tabular}{|l|l|l|}
\hline Ratings & Frequency & Percentage \\
\hline Exemplary & 4 & $20 \%$ \\
\hline Above average & 11 & $55 \%$ \\
\hline Average & 4 & $20 \%$ \\
\hline below average & 1 & $5 \%$ \\
\hline
\end{tabular}

As for teachers' computer literacy and Internet use, 55\% of the informants rated their ability, as computer and Internet users, as above average, followed by $20 \%$ as average, while $20 \%$ rated themselves as 'exemplary', and 5\% as below average. Such statistics manifest that the EFL instructors generally do possess Internet-related knowledge, but with varying degrees. In spite of the fact that only $29 \%$ of the respondents received formal training related to the Internet use in language teaching and learning, they all seem to possess the skills necessary to surf and use the Internet. This also reflects that there is considerable awareness regarding the importance of Internet applications in TEFL.

Q2) To what extent is the Internet related knowledge possessed by EFL instructors capitalized on to provide language learners with adequate language input?

Responses to items 1through 3, given in Table 2, show that the teachers in focus had a positive attitude towards the Internet and its classroom-related applications. Viewed as an immense source of information and learning resources, responses to items 4 through 9 indicate that the EFL instructors used the various sources of the Internet to provide learners with opportunities to practice the language. They also seem to encourage their students to obtain meaningful language input and to tackle, with the aid of the Internet-based language learning resources, the difficulties they may experience with the language. As a way of illustration, EFL learners appear to be encouraged to connect with their classmates and teachers, and this has a positive impact on their oral and written skills, as they are likely to pick up phrases and utterances used by their chatting classmates and teachers. Further, the data tallied and presented in Table 2 below show that the EFL instructors generally manipulate the Internet towards TEFL purposes to provide students with considerable language input.

Table2. Internet Utility in EFL Context

\begin{tabular}{|l|l|l|l|l|l|l|}
\hline & Items & SD & D & NS & A & SA \\
\hline 1 & I use the Internet to bring novelty and variety into my teaching. & $0 \%$ & $0 \%$ & $0 \%$ & $45 \%$ & $55 \%$ \\
\hline 2 & It elevates the level of my teaching. & $0 \%$ & $0 \%$ & $15 \%$ & $35 \%$ & $50 \%$ \\
\hline 3 & It makes my classes more creative and flexible. & $0 \%$ & $0 \%$ & $15 \%$ & $55 \%$ & $30 \%$ \\
\hline 4 & $\begin{array}{l}\text { I use the Internet to get authentic materials that can foster my } \\
\text { students' competence. }\end{array}$ & $0 \%$ & $10 \%$ & $15 \%$ & $35 \%$ & $40 \%$ \\
\hline 5 & It connects students with their classmates and teachers. & $5 \%$ & $10 \%$ & $10 \%$ & $40 \%$ & $35 \%$ \\
\hline 6 & It gives my students access to a wide range of resources. & $0 \%$ & $10 \%$ & $0 \%$ & $25 \%$ & $65 \%$ \\
\hline 7 & $\begin{array}{l}\text { It helps students work on their language problems and } \\
\text { difficulties. }\end{array}$ & $15 \%$ & $0 \%$ & $20 \%$ & $30 \%$ & $35 \%$ \\
\hline 8 & $\begin{array}{l}\text { I encourage my students to listen to English produced by native } \\
\text { speakers. }\end{array}$ & $0 \%$ & $0 \%$ & $10 \%$ & $20 \%$ & $70 \%$ \\
\hline 9 & $\begin{array}{l}\text { I advice my students to take online tests to test their language } \\
\text { proficiency. }\end{array}$ & $5 \%$ & $0 \%$ & $25 \%$ & $25 \%$ & $25 \%$ \\
\hline
\end{tabular}

Scrutinizing the informants' responses arranged in Table 2 shows several opportunities that the EFL teachers can direct for a better L2 learning. Responses to item 1 show that there is a high level of agreement among the participants that they utilize the Internet to make their classroom teaching more interesting and more suited to the needs and interests of the learners. Additionally, responses to item 2 show that $85 \%$ of the teachers agree that the Internet makes their teaching not only varied, but also meaningful. This is also reinforced by their comments in the open ended question that the teaching materials extracted from the Internet help create an environment conductive for language learning. Regarding the usefulness and authenticity of the Internet-derived learning materials, responses to items 3 and 4 clearly indicate that the Internet is an authentic source of leaning materials. Further, responses to item 5 indicate that $75 \%$ of the participants appear to encourage learners to use the language in their online conversations with their classmates and teachers. Communicating with friends locally, nationally and globally via the Internet can have a positive impact on their communication skills in L2. As far as item 6 of the questionnaire is concerned, 90\% of the teachers agree that the Internet can help learners lay their hands on materials and learning tools to positively enhance their overall competence in English. 
Likewise, participants' responses to item 7 indicate that accessibility to the Internet can assist learners in dealing with the language problems they are liable to encounter. Further, responses to item 8 show that $90 \%$ of the teachers agree that the Internet enables learners to have access to naturally occurring language extracts produced by native speakers. They, for instance, get the chance to listen to English produced with accurate pronunciation. Similarly, responses to item 9 indicate that accessibility and availability of online proficiency tests can help learners to find out more about their language competence and what language areas they still need to work on to further improve their language. Online interactions facilitated by the Internet can encourage timid students to use the language to express their ideas and opinions more freely. This is in harmony with the results of Shin and Son's (2007) and Noytim's (2006) studies.

Q3) what are the Internet-based tools that the EFL instructors employ to help learners improve their language skills?

As indicated in Table 3, 85\% of the teachers agree that online audio chats can help to get students exposed to authentic English so that they get the opportunity to improve their English pronunciation, and this can particularly help them to learn more about the prosodic features of the language such as intonation and stress. Besides, this will provide learners with opportunities to listen to different varieties of English. As far as EFL learners' reading and writing skills are concerned, 75\% of the EFL teachers believe that using emails and messengers can assist learners to be better readers and writers. This is echoed in Levy's (2009) study .One more thing is that responses to items 3, 5, 6, given in Table 3, show that the EFL teachers agree that the Internet provides students with the chance to use English communicatively outside the realms of the classroom.

Table3. The Internet as a Tool of Enhancing EFL Learning

\begin{tabular}{|l|l|l|l|l|l|l|}
\hline & Items & $\mathbf{N}$ & $\mathbf{R}$ & $\mathbf{O}$ & $\mathbf{U}$ & $\mathbf{A}$ \\
\hline 1 & $\begin{array}{l}\text { Audio chats expose my students to different authentic modes of } \\
\text { pronunciation, thus developing their listening skills }\end{array}$ & $0 \%$ & $10 \%$ & $5 \%$ & $35 \%$ & $50 \%$ \\
\hline 2 & $\begin{array}{l}\text { Emails and messengers help my students be better L2 readers } \\
\text { and writers. }\end{array}$ & $0 \%$ & $10 \%$ & $15 \%$ & $55 \%$ & $20 \%$ \\
\hline 3 & $\begin{array}{l}\text { Online activities help to foster sensitivity and tolerance towards } \\
\text { the speakers of the target language and culture }\end{array}$ & $10 \%$ & $5 \%$ & $10 \%$ & $55 \%$ & $20 \%$ \\
\hline 4 & $\begin{array}{l}\text { Variety of online materials meet my students' needs in different } \\
\text { linguistic levels }\end{array}$ & $0 \%$ & $0 \%$ & $20 \%$ & $30 \%$ & $50 \%$ \\
\hline 5 & $\begin{array}{l}\text { Social networks such as Facebook and Twitter help my students } \\
\text { to socialize with the world. }\end{array}$ & $5 \%$ & $0 \%$ & $20 \%$ & $30 \%$ & $45 \%$ \\
\hline 6 & Online contacts improve my students' communication skills. & $0 \%$ & $15 \%$ & $15 \%$ & $45 \%$ & $25 \%$ \\
\hline 7 & Internet-based learning can replace face-to-face teaching & $45 \%$ & $20 \%$ & $10 \%$ & $20 \%$ & $5 \%$ \\
\hline 8 & Internet-based activities can help lower learners' affective filter. & $0 \%$ & $10 \%$ & $50 \%$ & $25 \%$ & $15 \%$ \\
\hline
\end{tabular}

Similarly, social networks (Facebook, Twitter, etc.) are generally perceived to enhance interaction with people from different language backgrounds; $75 \%$ of the surveyed teachers agree that such social networking can provide opportunities for learners to exchange and discuss ideas, and opinions on different issues. Given the fact that EFL learners are not linguistically homogenous, the Internet, via English learning websites, allows learners to have access to materials and activities suited to their needs, interests and language ability levels. Simply put, learners can have the chance to interact with online materials that are specifically tailored to their needs and interests.

One more important point that deserves mention is that EFL teachers agree that Internet-based activities help EFL learners to feel at ease when engaging in verbal and written online interactions using Web 2.0 tools such as Facebook, Twitter, Skype, WhatsApp, etc. This is basically due to the fact that the Internet provides a learning environment that is learner-friendly and subsequently helps lower learners' affective filter. It is to be noted that $65 \%$ of the EFL instructors feel that it is quite unlikely for the Internet to replace face-to face teaching, and this is, in fact, in line with the findings obtained by Dudeney \& Hockly (2012), who stress the fact that the role played by language teachers in L2 classrooms is crucial and indispensible.

Furthermore, surveyed instructors believe that the Internet can play a motivating role in helping EFL learners to improve their listening skills. Consequently, this can have a positive impact on learners' pronunciation as online interactions with native speakers could help them deal with certain pronunciation problems or difficulties that they might encounter. Emails, for instance, can be a good 
learning tool as they positively impact learners' reading and writing skills. That is, EFL learners can access certain EFL/ESL websites that can be geared towards improving their reading and writing skills. Additionally, online communication and interaction with native speakers help to foster tolerance and empathy towards native speakers and the target culture (see Kitao \& kitao, 2001). In short, synchronous and asynchronous online interactions can improve not only learners' language skills but also their sociolinguistic competence, an important component of communicative competence that is usually insufficiently addressed by L2 teachers adopting conventional methods in their L2 classrooms.

Q (4) Are there any statistically significant differences with regards to Internet applications in TEFL based on age/college/gender variables?

Mann-Whitney and Kruskal-Wallis tests have been used to tackle question 4; the results are outlined in Tables 4, 5 and 6 below.

Table4. Results of Mann-Whitney Test Based on Gender

\begin{tabular}{|l|l|l|l|l|}
\hline & Dimension & Test & Sig. & Decision \\
\hline 1 & The Internet applications in TEFL & Mann-Whitney U Test & .067 & Retain null hypothesis \\
\hline 2 & Impact of Internet on EFL learners & Mann-Whitney U Test & .152 & Retain null hypothesis \\
\hline
\end{tabular}

As shown in Table 4, there are no statistically significant differences with regards to the Internet applications in TEFL and impact of the Internet on EFL learners based on gender variable where Sig. is .067 and .152 respectively. This is an obvious indication that both male and female EFL instructors at TU are aware that the Internet applications in TEFL play a major role in enhancing learners' language skills. That is, gender variable is not an influential factor of the Internet use in the context of the study.

Table5. Results of Mann-Whitney Test Based on College

\begin{tabular}{|l|l|l|l|l|}
\hline & Dimension & Test & Sig. & Decision \\
\hline 1 & Internet applications in TEFL & Mann-Whitney U Test & .157 & Retain null hypothesis \\
\hline 2 & Impact of Internet on EFL learners & Mann-Whitney U Test & .699 & Retain null hypothesis \\
\hline
\end{tabular}

According to Table 5, there are no statistically significant differences with regards to the Internet applications in TEFL and the impact of the Internet on EFL learners based on college affiliation variable where Sig. is .157 and .699 respectively. This obviously lends support to the fact that the EFL instructors in both colleges, Arts and Education, are aware of the fact that the Internet can play a vital role not only in enhancing learners' language skills, but also in further improving their communication skills. The two groups seem to generally agree that learners' ability to learn English correctly and appropriately can be considerably facilitated by the Internet.

Again, the college variable is a factor that has no direct effect on the Internet utilization. Like the variables of 'gender' and 'college', the age variable, as Table 6 shows, has no statistically significant difference with regards to Internet applications in TEFL and the impact of the Internet on EFL learners (Chi-Square is .397 and .658 respectively). Again, this shows that the participants, regardless of their age group, perceive the Internet to be useful and plays a facilitating role in language teaching and learning.

Table6. Results of Kruskal-Wallis Test Based on Age Variable

\begin{tabular}{|c|c|c|c|c|c|c|}
\hline \multicolumn{4}{|l|}{ Ranks } & \multirow{7}{*}{$\begin{array}{l}\text { Chi-Square } \\
397\end{array}$} & \multirow{7}{*}{$\begin{array}{l}\text { df } \\
3\end{array}$} & \multirow{2}{*}{$\begin{array}{l}\text { Asymp. Sig. } \\
.941\end{array}$} \\
\hline Dimension & Age & $\mathrm{N}$ & Mean Rank & & & \\
\hline \multirow{5}{*}{$\begin{array}{l}\text { Internet applications } \\
\text { in TEFL }\end{array}$} & $20-29$ & 9 & 11.28 & & & \\
\hline & $30-39$ & 9 & 10.06 & & & \\
\hline & $40-49$ & 1 & 10.00 & & & \\
\hline & $50-59$ & 1 & 8.00 & & & \\
\hline & Total & 20 & & & & \\
\hline \multirow{5}{*}{$\begin{array}{l}\text { Impact of Internet on EFL } \\
\text { learners }\end{array}$} & $20-29$ & 9 & 10.72 & \multirow[t]{5}{*}{.658} & \multirow[t]{5}{*}{3} & \multirow[t]{5}{*}{.883} \\
\hline & $30-39$ & 9 & 10.44 & & & \\
\hline & $40-49$ & 1 & 6.50 & & & \\
\hline & $50-59$ & 1 & 13.00 & & & \\
\hline & Total & 20 & & & & \\
\hline
\end{tabular}


Taken together, Tables 4, 5 and 6 clearly reflect the sort of awareness the EFL teachers have at both colleges, Arts and Education, towards the Internet integration in the EFL situation. Age, college affiliation and gender do not seem to directly influence the use and manipulation of the Internet in their language classrooms. This seems to be contradictory with Abu Samak's (2006) findings as for the age variable; Abu Samak reported a negative correlation with attitudes towards technology use; aged instructors appeared more reluctant to technology integration than the Internet-oriented generation of teachers who participated in that particular study.

As far as the responses of the participants to the open-ended question are concerned, the EFL instructors in question have generally emphasized the importance of the Internet in teaching and learning English in the EFL context. They also stressed the fact that raising teachers' and learners' awareness of the importance of the Internet in enhancing language learning should be given the attention it deserves.

Acknowledging the usefulness of social networks, the majority of the EFL instructors pointed out that learners can, for instance, use Facebook, with the monitoring of the teacher, to create a group devoted to dealing with the course concerns and issues. Creating such a group can help learners to share ideas with classmates and teachers, pose questions, express their viewpoints, etc. To this end, the Department of English at the Faculty of Education, for instance, has initiated a Facebook account to serve this purpose; it is a space where teachers and students can meet online to discuss issues of shared concerns. Informants further postulated that online communication can help solve certain pending problems, clarify certain ambiguities, and create useful materials to facilitate language learning for their learners.

\section{CONCLUSION AND RECOMMENDATIONS}

In this paper the use of the Internet by Taiz University EFL instructors is explored so as to find out how it is utilized in facilitating English language learning in such an EFL context. The analysis of the data clearly indicates that the EFL instructors positively think that the Internet is a powerful tool for English language learning and teaching. They, all in all, have a positive attitude towards the use and integration of the Internet to enhance EFL learning and teaching. Based on the obtained results, the instructors in focus believe that the use of the Internet enables them to bring novel ideas into their own language classes. They, for example, use language web sites available on the Internet to get materials on language activities that can appeal to their students' needs and language ability levels. Results also revealed that there are no statistically significant differences among the participants in terms of their use of the Internet in their classroom teaching on the basis of college affiliation, age or gender variables. Overall, the surveyed teachers tend to agree that the Internet plays an important role in enhancing learners' linguistic and communicative competencies.

Based on the findings of this study, the following recommendations can be suggested. To begin with, Internet-based language learning resources and tools should be made available in English classrooms, especially in the EFL context where accessibility to authentic and natural language is a major concern for many EFL teaches and practitioners. To help overcome this problem, English classrooms should be wired to the Internet so that EFL learners can easily gain access to the websites providing useful language activities and exercises. EFL instructors, moreover, should be adequately trained in how to fruitfully utilize the Internet and use it as an integral component in their language classes. English language instructors should be aware of the fact that the Internet can be a valuable source to introducing EFL learners to the target culture and this can have a positive impact on their overall communicative competence. English language instructors in Yemen and in many other similar parts of the world should not be lagging behind and they ought to keep abreast of the latest trends in the field of ELT and familiarity with how technology in general and instructional technology in particular can be utilized to make second/foreign language learning not only meaningful but also more natural. In a word, integration of the Internet technologies as part of EFL classroom curricula is, in fact, a necessity.

\section{FUTURE RESEARCH}

Because this study is essentially based on the perspectives and attitudes of $20 \mathrm{EFL}$ instructors, further research is still needed to shed more light on the use of the Internet in L2 learning and teaching. More concrete clear-cut answers can be obtained by means of conducting more in-depth studies that should focus more on the classroom use of the Internet and how it helps L2 learners to engage in real-time 
classroom language interactions. Further research is also needed to explore how blogs and mobile phones can be positively used in helping ESL/EFL learners develop better English proficiency in this part of the world and in other similar situations where English is taught as a foreign language. In a word, emerging technologies will continue to surprise language teachers and practitioners with new digitally sophisticated devices that can be geared towards aiding EFL learners to attain better and higher proficiency levels in English language, the world lingua franca. As a consequence, further research is actually needed to meticulously examine how the currently used instructional technologies contribute to elevating ELT in foreign language contexts, where real and meaningful language input can make a difference in how non-native language teachers and practitioners tackle EFL instruction.

Like any other study, this one has its own limitations. A possible shortcoming might be the smallness of the sample and the reliance on one method of data collection, that is, the questionnaires. Other data collection methods such as classroom observations and interviews can be used to glean a better and clearer picture as to how the Internet is actually used in language classrooms in EFL contexts. Put simply, future research into the area of Internet-assisted language teaching and learning should consider adopting a mixed-method approach to tackling this and other similar issues.

\section{REFERENCES}

[1] AL-Mekhlafi, A. (2004). The Internet and EFL Teaching: The Reactions of UAE Secondary School English Language Teachers. Journal of Language and Learning, 2 (2), 88-113.

[2] Crystal, D. (2006). Language and the Internet. Cambridge: Cambridge University Press.

[3] Dudeney, G. \& Hockly, N. ( 2012). ICT in ELT: How did we get here and where are we going? ELT Journal, 66(4), special issue, doi:10.1093/elt/ccs050

[4] Gündüz, N. (2005). Computer Assisted Language Learning (CALL). Journal of Language and Linguistic Studies, 1 (2), 193- 214.

[5] Hismanoglu, S. (2011). Attitudes of L2 teachers towards Internet-based foreign language teaching. Procedia Social Sciences, 3, 106-111.

[6] Kitao, K. \& Kitao, S. (2001). Teaching students to find Internet resources related to culture. In K. Cameron (Ed.), CALL: The challenge of change: Research and practice (pp. 143-150). Exter: Elm Bank publications.

[7] Levy, M. (2009). Technologies in use for second language learning. The Modern Language Journal, 93, 769-782. DOI:10.1111/j.1540-4781.2009.00972

[8] McDougald, J. (2009). The use of information and communication technology (ICT) in the EFL classroom as a tool to promote 12 (English) among non-native pre service English teachers (Master's thesis). University of Jaén, Spain.

[9] Moore, P. (1996). Reading and writing on the Internet. The Australian journal of language and literacy, 19 (4), 317-329.

[10] Noytim, U. (2006). The impact of Internet on English language teaching: A case study at Thai Rajabhat University (unpublished doctoral dissertation). University of Technology, Sydney.

[11] Pennington, M.(1996). The power of the computer in language education. In M. C. Pennington (Ed.), the power of CALL (pp. 1-14). Houston: Athelstan.

[12] Sperling, D. (1998). Dave Sperling's Internet guide: For English language teachers $2^{\text {nd }}$ ed.). Upper Saddle River, NJ: Prentice Hall Regents.

[13] Smith, B. (1997). Virtual realia .The Internet TESL Journal, 3, 7. Retrieved from http://iteslj.org/

[14] Singhal, M. (1997). The Internet and Foreign Language Education: Benefits and Challenges. The Internet TESL Journal, 3 (6), http://iteslj.org/

[15] Shin, H. \& Son, J. (2007). EFL Teachers' Perceptions and Perspectives on Internet Assisted Language Teaching. CALL-EJ Online, 8 (2), ISSN 1442-438X.

[16] Wu, W. Yen, L. \& Marek, M. (2011). Using online EFL interaction to increase confidence, motivation, and ability. Educational Technology \& Society, 14 (3), 118-129.

[17] Warschauer, M. (2000). CALL vs. electronic literacy: Re-conceiving technology in the language classroom. Retrieved from http://www.cilt.org.uk/research/resfor2/warsum1.htm 


\section{Appendix}

\section{Questionnaire for EFL Instructors}

Dear colleague,

Thank you for taking part in this survey. This questionnaire aims to collect data pertaining to your perspectives on the utility of the Internet as a means of fostering language learning opportunities in language classrooms in the local context. All information will be anonymous and confidential, and used only for the purpose of this study. You are welcome to contact the researchers for any clarification or if you want to know about the results of the study.

\section{Part I: Background Information}

Name (optional)

1. Sex: $\square$ Male

Female

2. Age group:
20-29
30-39
$40-49$
$50-59$
$60+$

3. College:

Education

Arts

4. Latest qualification:

$\square$ B.A

$\begin{array}{ll}\square & \mathrm{PhD} \\ \square & \text { Other (please specify) }\end{array}$

5. Specialization:

Literature

Linguistics

ELT

Part II: Your experience with Internet applications

6. Are you an Internet user?

$\square$ Yes

$\square$ No

7. Do you have access to the Internet at home?

$\square$ Yes $\square$ No

8. Are your classrooms wired for the Internet?

$\square$ Yes

$\square$ No

9. Have you received a training course on the use of the Internet in language classrooms?

$\square$ Yes

$\square$ No

10. Please rate yourself as a computer/Internet user.

$\square$ Exemplary

Average

Above average

Below average

Part III: Internet applications in TEFL

Please read through the items given in the table below and tick the closest to your opinion.

\begin{tabular}{|c|c|c|c|c|c|}
\hline $\begin{array}{c}\text { Scale }: \mathrm{SA}=\text { strongly agree } \mathrm{A}=\text { agree } \mathrm{NS}=\text { not sure } \\
\mathrm{D}=\text { disagree } \quad \mathrm{SD}=\text { strongly disagree }\end{array}$ & $\mathbf{S A}$ & $\mathbf{A}$ & NS & $\mathbf{D}$ & SD \\
\hline 1. I use the Internet to bring novelty and variety into my teaching. & & & & & \\
\hline 2. It elevates the level of my teaching. & & & & & \\
\hline 3. It makes my classes more creative and flexible. & & & & & \\
\hline $\begin{array}{l}\text { 4. I use the Internet to get authentic materials that can foster my students' } \\
\text { competence. }\end{array}$ & & & & & \\
\hline 5. It connects students with their classmates and teachers. & & & & & \\
\hline
\end{tabular}

International Journal on Studies in English Language and Literature (IJSELL)

Page $\mid 60$ 


\begin{tabular}{|ll|l|l|l|l|}
\hline \hline It gives my students access to a wider range of resources. & & & & & \\
\hline $7 . \quad$ It helps students work on their language problems and difficulties. & & & & & \\
\hline $8 . \quad$ I encourage my students to listen to English spoken by native speakers. & & & & & \\
\hline $\begin{array}{l}\text { 9. I advice my students to take online tests to test their language } \\
\text { proficiency. }\end{array}$ & & & & & \\
\hline
\end{tabular}

Part IV: Impact of the Internet on EFL learners

\begin{tabular}{|c|c|c|c|c|c|}
\hline & always & usually & often & rarely & never \\
\hline $\begin{array}{l}\text { 10. Audio chats help to get my students exposed to } \\
\text { authentic different modes of pronunciation. }\end{array}$ & & & & & \\
\hline $\begin{array}{l}\text { 11. Emails and messengers help my students be better L2 } \\
\text { readers and writers. }\end{array}$ & & & & & \\
\hline $\begin{array}{l}\text { 12. Online activities help my students to foster sensitivity } \\
\text { and tolerance towards L2 speakers and the target } \\
\text { culture. }\end{array}$ & & & & & \\
\hline $\begin{array}{l}\text { 13. Variety of online materials meet my students' needs in } \\
\text { different linguistic levels }\end{array}$ & & & & & \\
\hline $\begin{array}{l}\text { 14. Social networks such as Face-book and Twitter help } \\
\text { my students to socialize with the world. }\end{array}$ & & & & & \\
\hline $\begin{array}{l}\text { 15. Online contacts improve my students' communication } \\
\text { skills. }\end{array}$ & & & & & \\
\hline $\begin{array}{l}\text { 16. Internet-based learning can replace face-to-face } \\
\text { teaching }\end{array}$ & & & & & \\
\hline $\begin{array}{l}\text { 17. Internet-based activities can help lower learners' } \\
\text { affective filter. }\end{array}$ & & & & & \\
\hline
\end{tabular}

\section{Part V: Comments and suggestions}

Please use the space given below to write down any further comments or suggestions that you might have.

Thank you for your cooperation 


\section{AUTHORS' BIOGRAPHY}

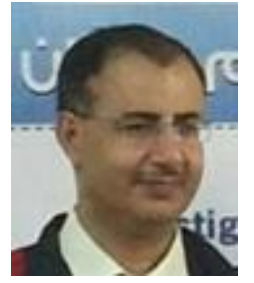

Abdulhafeed Saif Modhish, is an assistant professor of Applied Linguistics at English department, Faculty of Education, Taiz University. He did his MA in TESOL at Arizona State University and $\mathrm{PhD}$ at JNU, India

His research interests include SLA, Sociolinguistics, Discourse Analysis, Learner English, Curriculum Design and Analysis.

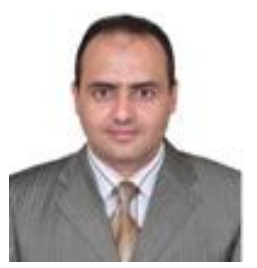

Abdu M. Talib Al-Kadi, is a faculty member at Language and Translation Center, Ibb University, Yemen. He obtained his MA in Applied Linguistics and is currently a $\mathrm{PhD}$ research student in Tunisia. He has been teaching English as EFL at Taiz University for about 7 years. He also taught English as ESP to the students of dentistry and engineering at Ibb University. His major areas of interest include CALL, MALL, SLA and ESP. 